Nota

\title{
ENRAIZAMENTO IN VITRO DE UM PORTA-ENXERTO DE MACIEIRA EM DIVERSOS SUBSTRATOS
}

\author{
Moacir Pasqual ${ }^{1,3 *}$; Adriano Bortolotti da Silva ${ }^{2,4} ;$ Anna Lygia de Rezende Maciel ${ }^{2,4}$; André Barretto \\ Pereira $^{2,5}$; João Mauricio Cavalcante-Alves ${ }^{1,5}$ \\ ${ }^{1}$ Depto de Agricultura - UFLA, C.P. 37 - CEP: 37200-000 - Lavras, MG. \\ ${ }^{2}$ Pós-Graduando em Fitotecnia - UFLA. \\ ${ }^{3}$ Bolsista CNPq. \\ ${ }^{4}$ Bolsista CAPES. \\ ${ }^{5}$ Bolsista FAPEMIG. \\ *Autor correspondente <mpasqual@ufla.br>
}

RESUMO: O processo tradicional para produção de porta-enxertos de macieira é o de mergulhia, que apresenta baixa eficiência. As técnicas de cultura de tecidos têm sido uma alternativa viável, pois permitem aumentar 0 rendimento no processo de multiplicação, evitam disseminação de doenças e mantém as características da planta mãe. $O$ presente trabalho teve como objetivo identificar um substituto do ágar no meio de cultivo para 0 enraizamento do porta-enxerto de macieira (Malus domestica Borkh.) cv. M-7. O delineamento experimental foi inteiramente casualizado, em esquema fatorial $5 \times 4$ com 4 repetições e 4 explantes por parcela. As concentrações dos sais do meio MS utilizadas foram $0 \%, 50 \%, 100 \%, 150 \%$ e $200 \%$ e os substratos foram ágar (3,0 e 6,0 $\left.\mathrm{g} \mathrm{L}^{-1}\right)$, vermiculita e areia, em todas as combinações possíveis. Em todos os tratamentos o meio de cultura MS foi suplementado com 1,0 mg L ${ }^{-1}$ de IBA. As avaliações foram efetuadas 45 dias após a inoculação através dos seguintes parâmetros: altura de brotos, peso da matéria fresca e seca da parte aérea e do sistema radicular. Constatou-se que o melhor desenvolvimento da parte aérea e sistema radicular é obtido com o uso de ágar 3,0 e 6,0 $\mathrm{g} \mathrm{L}^{-1}$, independentemente da concentração de sais. $\mathrm{O}$ uso de areia apresenta resultados similares ao ágar quando a concentração de sais é de $100 \%$ do meio MS.

Palavras-chave: Malus domestica, cultura de tecidos, meio de cultura

\section{IN VITRO ROOTING OF AN APPLE ROOTSTOCK IN SEVERAL SUBSTRATES}

\begin{abstract}
The traditional process for production of apple rootstocks presents low efficiency. The tissue culture techniques have been a viable alternative, because they allow to increase the multiplication process, they avoid dissemination of diseases and maintains the plant mother's characteristics. The objective of this work is identify a substitute for agar in the growth media for the rooting of apple (Malus domestica Borkh.) rootstock, cultivar M-7. The experimental design was completely randomized, in a 5x4 factorial scheme, with 4 replications and 4 explants per plot. The salt concentrations of the medium MS were $0 \%, 50 \%, 100 \%, 150 \%$ and $200 \%$. The substrates were agar, vermiculite and sand, in all possible combinations. The MS medium was placed into flask and autoclaved at $121^{\circ} \mathrm{C}$ for 20 minutes. The growth medium was supplied with $1.0 \mathrm{mg} \mathrm{L}^{-1}$ IBA. The evaluations were monitored through the following parameters: shoot height, dry weight and fresh weight matter of shoot and root system. The best growth shoots and root systems are obtained with the use of agar 3.0 and $6.0 \mathrm{~g} \mathrm{~L}^{-1}$, regardless of the salt concentrations. The use of sand gave similar results as compared to agar, when the salts concentration was $100 \%$ of the MS medium.
\end{abstract}

Key words: Malus domestica, tissue culture, culture medium

\section{INTRODUÇÃO}

O processo tradicional para produção de portaenxertos de macieira é o de mergulhia, que apresenta baixa eficiência. As técnicas de cultura de tecidos têm sido uma alternativa viável, pois permitem aumentar 0 rendimento no processo de multiplicação, evitam disseminação de doenças e mantém as características da planta mãe (Correa, 1990; Yui, 1990).

Experimentos realizados in vitro têm demonstrado que concentrações e tipo de sais minerais utilizados nos diferentes meios de cultivo promovem efeitos significativos na rizogênese (Jones et al., 1979; Snir \& Erez, 1980; Sriskandarajah \& Mullins, 1981). Entretanto, Zimmerman \& Broome (1979) não observaram efeito significativo da adição de sais minerais no meio de cultivo, para o enraizamento das cultivares de macieira dos grupos Delicious e Mclntosh.

O enraizamento in vitro de brotos de macieira é conseguido com os sais de MS (Murashige \& Skoog 1962), os quais podem ser reduzidos a 3/4 (Dunstan et al., 1985), a $1 / 2$ (Sriskandarajah \& Mullins, 1981), a $1 / 3$ (Werner \& Boe, 1980) e, até mesmo, a 1/4 (George \& Sherrington, 
1984). Para a indução do enraizamento, é indicado o uso de um meio com auxina, e posteriormente outro isento de auxina para o desenvolvimento das raízes (Grattapaglia \& Machado, 1998). O regulador vegetal mais indicado para induzir o enraizamento de brotos de macieira é o ácido indolbutírico (IBA). Concentrações variando entre 0,5 e 2,0 $\mathrm{mg} \mathrm{L}^{-1}$ de IBA são as mais utilizadas (Jones et al., 1979; Sriskandarajah \& Mullins, 1981). Snir \& Erez (1980) obtiveram 100\% de enraizamento dos porta-enxertos MM-104, MM-106 e MM109, utilizando $1,0 \mathrm{mg} \mathrm{L}^{-1}$ de IBA no meio de cultivo.

$\mathrm{O}$ ágar é $\mathrm{O}$ agente solidificante tradicionalmente utilizado nos meios sólidos e semi-sólidos (Caldas et al., 1990). Segundo Singha (1982), ele é o ingrediente mais caro do meio de cultura. Alguns autores, visando reduzir o custo de produção de porta-enxertos de macieira, vêm testando substitutos para o ágar, como por exemplo, amido de milho e mandioca (Fortes et al., 1994). Apesar de ser o agente solidificante mais utilizado, diversos autores têm citado problemas na qualidade de enraizamento, que pode significar baixa taxa de sobrevivência das plântulas na fase de aclimatação (Lane, 1992). Hutchinson (1984), trabalhando com macieira, observou pequeno crescimento das raízes com ágar, apesar de apresentar mais de $90 \%$ de iniciação radicular. Segundo Pierik (1988), as raízes formadas in vitro não se apresentam totalmente funcionais quando transferidas in vivo, geralmente senescendo após o plantio. Do mesmo modo, Debergh \& Maene (1981) e Simmonds (1983) afirmaram que as raízes crescidas em ágar geralmente não possuem pêlos absorventes, podendo vir a morrer logo após o transplante. Zimmerman (1981) cita que o enraizamento em ágar é insatisfatório, devido ao volume de calo produzido, com as raízes formando-se acima deles.

Caldas et al. (1990) afirmam que a utilização de vermiculita umedecida com solução nutritiva pode favorecer a formação de raízes, devido a alta aeração que proporciona. A aeração é importante para a formação de raízes adventícias segundo vários autores (Sriskandarajah \& Mullins, 1981; Hutchinson,1984; Simmonds, 1983; Avanzato et al.,1993). Zimmerman \& Broome (1979) obtiveram melhores resultados com a utilização de vermiculita e vermiculita-perlita do que com ágar no enraizamento de diversas macieiras. Leite (1995) concluiu que a vermiculita pode substituir o ágar no enraizamento in vitro da pereira cv. Bartlett e do clone $\mathrm{OH} x$ F 97, induzindo um sistema radicular ramificado e com pêlos absorventes. Entretanto Hutchinson (1984), na cultivar de macieira Northen Spy, não obteve resposta superior da vermiculita em comparação ao ágar.

O presente trabalho teve por objetivo identificar um substituto para o ágar no enraizamento do porta enxerto de macieira M-7.

\section{MATERIAL E MÉTODOS}

O trabalho foi desenvolvido no Laboratório de Cultura de Tecidos, do Departamento de Agricultura, da Universidade Federal de Lavras (UFLA), Lavras-MG. Foram utilizados explantes de $2 \mathrm{~cm}$ de comprimento do porta-enxerto de macieira M-7 (Malus domestica Borkh.) preestabelecidos in vitro.

O experimento foi realizado sob condições assépticas, sendo testados diferentes concentrações do meio de cultura MS nas proporções $0 \%, 50 \%, 100 \%$, $150 \%$ e $200 \%$ e os substratos ágar, vermiculita e areia, em todas combinações possíveis. Para todos os tratamentos, o meio de cultura foi suplementado com $1,0 \mathrm{mg} \mathrm{L}^{-1}$ de IBA.

$\mathrm{O}$ meio de cultura teve o $\mathrm{pH}$ ajustado para $5,9 \mathrm{e}$ foi solidificado com 3,0 e 6,0 $\mathrm{g} \mathrm{L}^{-1}$ de ágar. No caso dos substratos vermiculita e areia, estes foram distribuídos nos frascos e logo após embebidos com o meio MS, conforme os tratamentos. Os frascos foram vedados com tampas plásticas e levados para autoclavagem por 20 minutos a $120^{\circ} \mathrm{C}$. Após o preparo do meio, foram introduzidos 4 explantes por frasco. Em seguida, o material foi transferido para sala de crescimento e mantido à temperatura de 27 $\pm 1^{\circ} \mathrm{C}$ e fotoperíodo de 16 horas, com intensidade luminosa de $20 \mu \mathrm{M} \mathrm{m}^{-2} \mathrm{~s}^{-1}$.

O delineamento experimental utilizado foi inteiramente casualizado, em esquema fatorial $5 \times 4 \mathrm{com} 4$ repetições e 4 explantes por parcela. As avaliações de altura dos brotos, peso da matéria fresca total e seca da parte aérea e do sistema radicular, foram realizadas aos 45 dias.

\section{RESULTADOS E DISCUSSÃO}

A TABELA 1 mostra que, para altura de plantas, o ágar 3,0 ou $6,0 \mathrm{~g} \mathrm{~L}^{-1}$ apresentaram os melhores resultados. A altura de plantas foi influenciada significativamente pelas concentrações de sais apenas no substrato areia. Para os demais substratos, os níveis de sais do MS não mostraram efeito significativo.

A Figura 1 demonstra que a altura de plantas aumentou a medida que foram elevadas as concentrações de sais do meio MS até o ponto máximo de $79,87 \%$, que correspondeu a 2,70 $\mathrm{cm}$ de altura da planta. Acima desta concentração passou a haver um efeito prejudicial. Este resultado demonstra que o substrato areia pode fornecer condições para um melhor enraizamento, conforme citam Caldas et al. (1990) e Zimmerman \& Broome (1979). A areia, bem como a vermiculita e outros componentes do substrato, podem propiciar melhor aeração e, consequentemente, melhor formação do sistema radicular, concordando com afirmações de Sriskandarajav \& Mullins (1981), Simmonds (1983), Houtchinson (1984) e Avanzato et al. (1993). Se houver um sistema radicular melhor formado, automaticamente a planta apresentar-se-á mais desenvolvida.

Por outro lado, o peso da matéria fresca da parte aérea e do sistema radicular foram influenciados significativamente pelas concentrações de sais apenas em ágar 6,0 $\mathrm{g} \mathrm{L}^{-1}$ (Figuras 2 e 3). Para ambos os parâmetros, na medida em que a concentração de sais foi elevada houve um conseqüente aumento do peso da 
TABELA 1 - Altura de brotos, peso da matéria fresca da parte aérea e do sistema radicular para os diferentes substratos (Médias de 4 repetições).

\begin{tabular}{lccc}
\hline Tratamento & $\begin{array}{c}\text { Altura de } \\
\text { brotos }\end{array}$ & $\begin{array}{c}\text { Peso da } \\
\text { matéria fresca } \\
\text { da parte aérea sistema radicular }\end{array}$ & $\begin{array}{c}\text { Peso da matéria } \\
\text { fresca do }\end{array}$ \\
\hline Ágar $6 \mathrm{~g} \mathrm{~L}^{-1}$ & $3,09 \mathrm{a}$ & $0,60 \mathrm{a}$ & $0,023 \mathrm{a}$ \\
Ágar $3 \mathrm{~g} \mathrm{~L}^{-1}$ & $2,72 \mathrm{a}$ & $0,30 \mathrm{~b}$ & $0,015 \mathrm{~b}$ \\
Areia & $1,72 \mathrm{~b}$ & $0,47 \mathrm{~b}$ & $0,000 \mathrm{~b}$ \\
Vermiculita & $1,52 \mathrm{~b}$ & $0,03 \mathrm{c}$ & $0,000 \mathrm{~b}$ \\
\hline
\end{tabular}

*Médias seguidas pela mesma letra não diferem estatisticamente pelo teste de Tukey a $5 \%$.

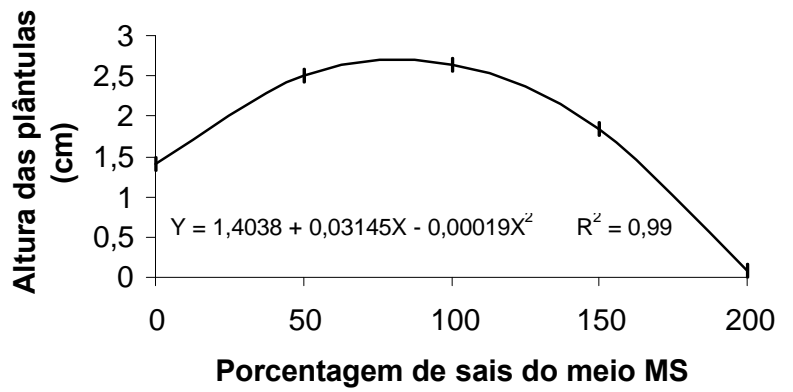

Figura 1 - Altura de brotos de macieira cv. M-7 em diferentes concentrações de sais do meio de cultura MS e utilizando areia como substrato.

matéria fresca da parte aérea, com ponto máximo em $149,57 \%$ e do sistema radicular com ponto máximo em $130,98 \%$.

Da mesma forma que em altura de plantas, ágar 3,0 e $6,0 \mathrm{~g} \mathrm{~L}^{-1}$ propiciaram melhores resultados que areia e vermiculita (TABELA 1). Estes dados aparentemente divergentes podem ser explicados pelo fato de que em areia ocorreu $\mathrm{o}$ alongamento de poucos brotos, enquanto que na presença de ágar $6,0 \mathrm{~g} \mathrm{~L}^{-1}$, brotos surgiram em maior número porém de tamanho menor, os quais resultaram em maior peso da matéria fresca. Estes pequenos brotos, uma vez bem enraizados, também produziram sistema radicular.

Para peso da matéria fresca de plantas, como a interação entre níveis do MS e substratos não foi significativa, estes fatores foram analisados independentemente. A Figura 4 mostra o aumento no peso da matéria seca até a concentração de $121,8 \%$ dos sais do meio de cultura MS (ponto de máxima) e que a partir deste ponto valores foram reduzindo. No que diz respeito aos substratos (Figura 5), de acordo com teste de Tukey, ágar 3,0 e 6,0 $\mathrm{g} \mathrm{L}^{-1}$ demonstraram maior peso da matéria seca do que vermiculita e areia.

O melhor desenvolvimento da parte aérea e do sistema radicular é obtido com o uso de ágar 3,0 a $6,0 \mathrm{~g}$ $\mathrm{L}^{-1}$, independentemente das concentrações de sais. $\mathrm{O}$ uso de areia apresenta resultados similares ao ágar, quando a concentração de sais é de $100 \%$ do MS.

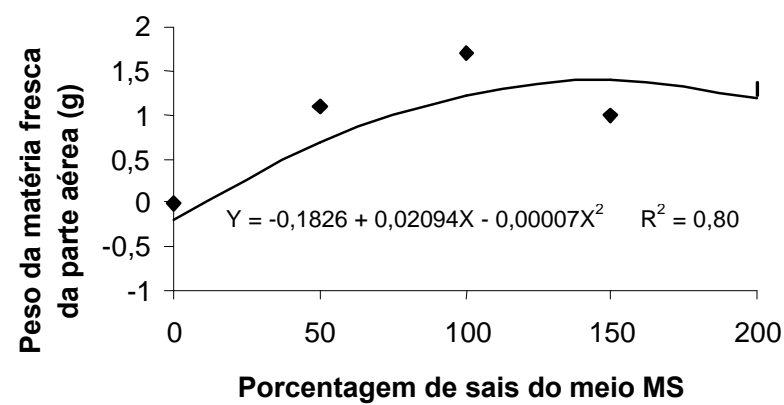

Figura 2 - Peso da matéria fresca da parte aérea de brotos de macieira cv. M-7 em diferentes concentrações dos sais do meio de cultura 'MS' e utilizando ágar $\left(6,0 \mathrm{~g} \mathrm{~L}^{-1}\right)$ como substrato.

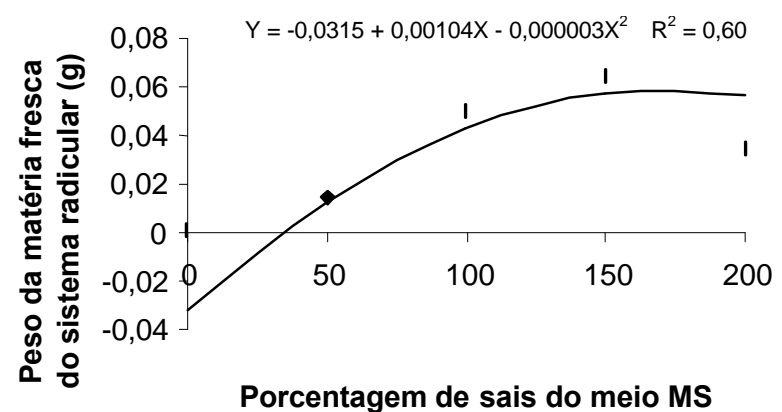

Figura 3 - Peso da matéria fresca do sistema radicular de brotos de macieira cv. M-7 em diferentes concentrações dos sais do meio de cultura 'MS' e utilizando ágar $\left(6,0 \mathrm{~g} \mathrm{~L}^{-1}\right)$ como substrato.

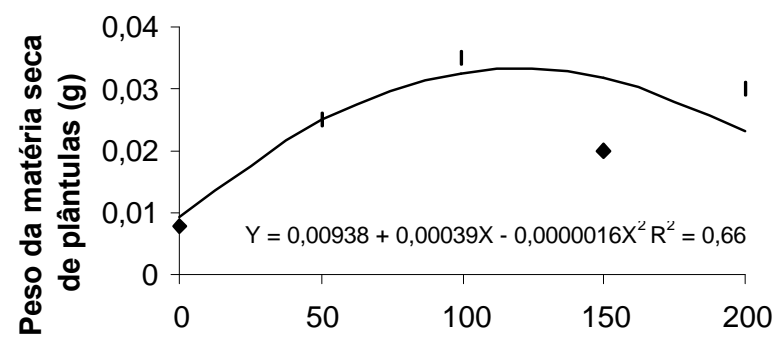

Porcentagem de sais do meio MS

Figura 4 - Peso da matéria seca de plântulas de macieira cv. M-7 em diferentes concentrações dos sais do meio MS.

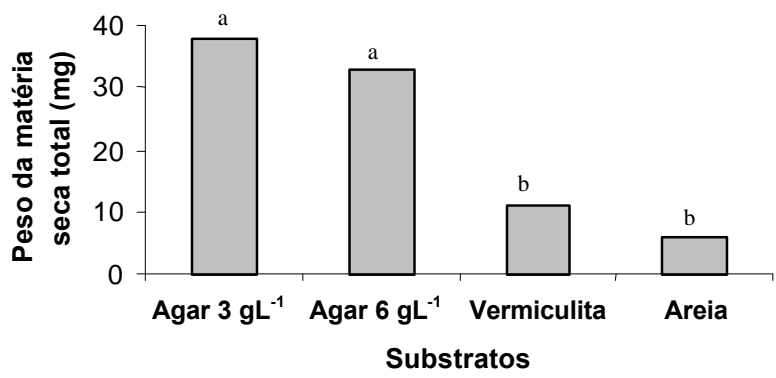

Figura 5 - Peso da matéria seca total de macieira cv. M-7 em diferentes substratos (Médias seguidas pela mesma letra não diferem estatisticamente pelo teste de Tukey a $5 \%$ ). 


\section{AGRADECIMENTOS}

À FAPEMIG (Fundação de Amparo à Pesquisa do Estado de Minas Gerais) pelo apoio financeiro.

\section{REFERÊNCIAS BIBLIOGRÁFICAS}

AVANZATO, D.; CHERUBINI, S.; JAQUE, E. Pottenzialità di radicazione diretta e ambientamento di microtalee di portinnesti di melo multiplicati in vitro. Rivista di Fruticoltura, v.16, p.87-90, 1993.

CALDAS, L.S.; HARIDASAN, P.; FERREIRA, M.E. Meios nutritivos. In: TORRES, A.C.; CALDAS, L.S. (Ed.) Técnicas e aplicações da cultura de tecidos de plantas. Brasília: ABCTP; EMBRAPA, CNPH, 1990. p.340-345.

CORREA, D.M. Enraizamento in vitro de porta enxerto de macieira (Malus x domestica Borck). Lavras, 1990. 50 p. Dissertação (Mestrado) - Escola Superior de Agricultura de Lavras.

DEBERGH, P.C.; MAENE, L.J. A scheme for commercial propagation of ornamental plants by tissue culture. Scientia Horticulturae, v.14, p.335-345, 1981.

DUNSTAN, D.I.; TURNER, K.E.; LAZAROFF, W.R. Propagation in vitro of apple rootstock M.4: effects of phytohormones on shoot quality. Plant Cell, Tissue and Organ Culture, v.4, p.55-60, 1985.

FORTES, G.R.L.; ZANOL, G.C.; CONCEIÇÃO, A.M.; SILVA, E.S.B. Uso de amido de mandioca como agente solidificante para enraizamento do porta-enxerto de macieira Marubakaido. In: CONGRESSO BRASILEIRO DE FRUTICULTURA 12., Salvador, 1994. Resumos. Salvador: SBF, 1994. v.2, p.610-611.

GEORGE, E.F.; SHERRINGTON, P.D. Factors affecting growth and morphogenesis. In: GEORGE, E.F.; SHERRINGTON, P.D. (Ed.) Plant propagation by tissue culture. London: Exegetics, 1984. cap.5, p.125-171.

GRATTAPAGLIA, D.; MACHADO, M.A. Micropropagação. In: TORRES, A.C.; CALDAS, L.S.; BUSO, J.A. (Ed.) Cultura de tecidos e transformação genéticas de plantas. Brasília: EMBRAPA, SPI, 1998. p.183-260.

HUTCHINSON, J.F. Factors affecting shoot proliferation and root initiation in organ cultures of the apple 'Northern spy'. Scientia Horticulturae, v.22, p.347-358,1984.
JONES, D.P.; PONTIKIS, C.A.; HOPGOOD, M.E. Propagation in vitro of five scion cultivars. Journal of Horticultural Science, v.54, p.235-238, 1979.

LANE, W.D. Micropropagation of apple (Malus domestica Borkh.). In: BAJAJ, Y.P.S. (Ed.) High-tech and micropropagation II. Berlin: Springer-Verlag, 1992. p.230-243. (Biotechnology in Agriculture and Forestry, 18)

LEITE, G.B. Efeito de reguladores de crescimento, substratos, sacarose e intensidade luminosa na micropropagação de pereira (Pyrus communis L.) cv. Bartlett e do clone $\mathrm{OH} \times \mathrm{F}$ 97. Pelotas, 1995. 50p. Tese (Doutorado) - Universidade Federal de Pelotas.

MURASHIGE, T.; SKOOG, F. A revised medium for rapid growth and biossays with tobacco tissue cultures. Physiologia Plantarum, v.15, p.473-497, 1962.

PIERIK, R.L.M. Handicaps for the large scale commercial application of micropropagation. Acta Horticulturae, v.230, p.63-71, 1988.

SINGHA, S. Influence of Malus sp. 'Almey' and Pyrus communis 'Seckel'. Journal of the American Society for Horticultural Science, v.107, p.657-660, 1982.

SIMMONDS, J. Direct rooting of micropropagated M26 apple rootstocks. Scientia Horticulturae, v.21, p.233-241, 1983.

SNIR, I.; EREZ, A. In vitro propagation of malling merton apple rootstocks. HortScience, v.15, p.597-598, 1980.

SRISKANDARAJAH, S.; MULLINS, M.G. Micropropagation of Granny Smith apple: factors affecting root formation in vitro. Journal of Horticultural Science, v.56, p.71-76, 1981.

WERNER, E.M.; BOE, A.A. In vitro propagation of malling 7 apple rootstock. HortScience, v.15, p.509-510, 1980.

YUI, E. Multiplicação in vitro de porta enxerto de macieira (Malus x domestica Borck). Lavras, 1990. 69p. Dissertação (Mestrado) - Escola Superior de Agricultura de Lavras.

ZIMMERMAN, R.H. Micropropagation of fruit plants. Acta Horticulturae, v.120, p.217-222, 1981.

ZIMMERMAN, R.H.; BROOME, O.C. In vitro propagation of apple cultivars. HortScience, v.14, p.478, 1979.

$\overline{\text { Recebido em } 01.10 .99}$ 